\title{
Формирование казахской советской бюрократии в 1920-е годы: большевизация или этнизация?ำ
}

\author{
Formowanie się biurokracji sowieckiej w latach dwudziestych XX w.: \\ bolszewizacja czy etnizacja?
}

\begin{abstract}
STRESZCZENIE:
Utworzenie państwa sowieckiego, jego transformacja oraz stabilizacja w latach 20. i 30. XX w. na przykładzie formowania się i restrukturyzacji elit politycznych Kazachskiej Autonomicznej Republiki Rad, stanowiącej organiczną część nomenklatury Związku Sowieckiego, obrazuje dynamikę kultury politycznej i ambiwalentny charakter etnopolityki sowieckiej. Personalizacja stosunków zarządu i podwładności, dynamika rozwoju aparatu biurokratycznego oraz jego kultura świadczą o wielowątkowym charakterze wzajemnych stosunków społeczeństwa tradycyjnego i o pojawiających się czynnikach modernizacyjnych. Ważnymi kwestiami były sposoby wzmocnienia kultury politycznej państwowości federacyjnej drogą konsolidacji elity rządzącej oraz wzmocnienia obopólnych relacji między władzami centralnymi Związku Sowieckiego a władzami republik wchodzących w jego skład. Autorka analizuje procesy zachodzące w formowaniu się biurokracji sowieckiej w Kazachstanie. Przedstawia stopień i płaszczyzny jej unifikacji lub modyfikacji pod wpływem czynników etnicznych i społecznych, a także osobliwości i procesy modernizacyjne zachodzące w jej obrębie.
\end{abstract}

Słowa kluczowe: Kazachstan, Związek Sowiecki, bolszewizacja, biurokracja, polityka

\section{ПРОБЛЕМЫ ФОРМИРОВАНИЯ СОВЕТСКОЙ БЮРОКРАТИИ}

Впервые в новейшей истории все крупные народы, получившие национально-государственные образования, в т.ч. казахское обще-

${ }^{1}$ Referat wygłoszony na IX Światowym Kongresie ICCEES (International Council for Central and East European Studies) w Tokyo (Chiba - Makuhari), w dniach 3-8 VIII 2015, sekcja „Kazakh Officials since the 19th century to the 1920s-30s: Position, Rank and Career". 
ство, институционализировади этничность в политическом и административно-территориальном пространстве страны, что и обусловило исключительную роль национальной бюрократии. Сама система органов власти и управления в отличие от дореволюционной становилась намного более сложной и разветвленной: 1) партийные органы, 2) советы во главе с исполкомами, 3) хозяйственные структуры, 4) освобожденный аппарат общественных организаций (каждая ветвь от краевых до волостных и даже аульно-сельских аппаратов) - все эти звенья необходимо было наполнить кодичественно, обеспечить маио-мальский профессионализм и одновременно преобладание в них представителей самоопределившегося этноса.

В частности, в 1920-1925 гг. в республике было 11 наркоматов, CHX, Управление почтой и телеграфом, ЧК. При правительстве были Центральное статистическое управление (1925 г.), промышленное бюро, Госплан, Экосо, Совет труда и обороны и т.д. - по аналогии с общероссийскими и союзными. В 1926 г. вместе с СНК и КазЦИК наркоматов и управлений в КАССР было 23, в 1932 г. - 15 наркоматов и основных краевых органов. При наркоматах создавались всевозможные ведомства, например, Управление уполномоченного Наркомата внешней торговди с аппаратом в 11 чел., позднее он вырос до 39 чел.; штат Киргосторга в 1922 г. составил 113 чел. На местах штат был раздичным - в Кустанайском агентстве, к примеру, он состоял из 30 чел., в Уральском - 22 чел., Букеевском - $4^{2}$.

Советские органы власти строились по всему СССР единообразно: региональные и местные съезды советов избиради руководство, которое входило в исполнитедьные комитеты (губернские и областные, уездные и районные, волостные и сельские-аульные). В 1920 г., например, в Семипалатинской губернии было 4 уезда и 135 волостей, в 1921 г. - 6 уездов и 177 волостей, в Акмолинской (1921 г.) - 4 уезда и 133 волости ${ }^{3}$. Председатели сельсоветов, волостных и районных исполкомов отражали не социально-родственные взаимосвязи, а классовые и идеологические приоритеты. Постепенно состав исполкомов разрастался в соответствии с народнохозяйственными секторами и социальной инфраструктурой места. Роль посредников-атками-

\footnotetext{
${ }^{2}$ Киргосторг. Обзор деятельности за первый год существования (с 1-го августа 1922 2. по 1-е октября 1923 г.), орrac. И. М. Расторгуев, Оренбург 1923, 23-27, 34, 58, 60, 65, 77; Вехи консолидациии. Из опыта партийных организацчий Казахстана в решении национального вопроса в 1917-1927 г2. (К 70-летию Компартии Казахстана). Сб. документов, Алма-Ата 1990, 84-95.

${ }^{3}$ Zob. О. А. Яковенко, История административно-территориального деления Центрального Казахстана в ХХ веке, „Вестник КарГУ” 2005, nr 2(38), 48.
} 
неров и переводчиков стали играть всевозможные активисты общественных организаций, санкционированных властью. Выборные органы общественных организаций - профсоюзов, комсомола, Кошчи, ОСОАВИАХИМ, Общество „Долой неграмотность” и т.д. строились аналогично советским. Наиболее важными были профсоюзы (в т.ч. профсоюз советских работников) и комсомод, аппараты которых возглавляли коммунисты - избранные лидеры организаций, являвшиеся освобожденными от другой работы штатными сотрудниками и входившие в состав партийной номенклатуры. Административнотерриториальные трансформации сопровождались переформатированием всех управленческих звеньев.

Прежде всего новая вдасть столкнулась с крайним дефицитом людей. Коммунисты-казахи, служившие главным резервом формирования чиновничества, были крайне малочисленны. В 1922 г. удельный вес казахов в парторганизации республики не превышал $20 \%$, причем стаж до 1917 г. имели 0,3-0,4\% ${ }^{4}$. На 1-й облпартконференции (июнь 1921 г.) из 162 делегатов казахов было 19, высшее образование имели 12 чел., среднее - 415. По данным Киробкома партии, на 1 сентября 1923 г. за исключением Адаевского и Тургайского уездов числилось 588 ответработников уездного, губернского и краевого масштаба' 6 . В мае 1924 г. в составе Киробкома было 10 казахов и 9 русских (2 секретаря - русский и казах), из них 12 с мест, в т.ч. секретари всех губкомов. Из 10 членов первого состава Президиума КазЦИК казахов было 6, из 14 членов правительства (наркомов) - 5. Из 190 лидеров КАССР насчитывалось „туземцев 38, нетуземцев, говорящих на туземном языке, $-6^{\prime \prime}$.

Если иметь в виду структуру республиканской парторганизации как основы советского управленческого класса, то важно отметить: партийную элиту в 1920-1921 гг. представляли 7 руководителей губкомов партии, секретари 44 уездных, 23 районных, 10 подрайонных городских и 50 водостных комитетов РКП(б), т.е. 134 человека, без учета руководства КАССР. К началу 1925 г. после территориальных изменений и определенного упорядочения структуры численность

${ }^{4}$ И. В. Сталин, Сочинения, t. 4, Москва 1947, 360-361; Д. А. Аманжолова, Казахское общество в 1-й четверти ХХ века: проблемь этноидентификации, [w:] Россия и Казахстан: проблеми истории (XX - начало XXI в6.), Москва 2006, 52; Вопросы истории Компартии Казахстана, выпуск 6, Алма-Ата 1969, 113. 115.

${ }^{5}$ Протоколь Первой Киргизской областной конференции РКП(б), Алма-Ата 1935,

6 Российский Государственный Архив Социально-Политической Истории (РГАСПИ), фонд 17, опис 67, дело 83, k. 8-9.

${ }^{7}$ РГАСПИ, фонд 17, опис 68, дело 189, k. 35-42. 
регионального и местного партийного руководства составила 214 чел. Состав Киргизского (Казахского) обкома партии с 1921 по 1925 гг. вырос с 14 до 28 чел. Кроме секретарей (первый и второй - в 1923 г. не избирался), аппарат главного парторгана постепенно разрастался: 4 функциональных отдела имели 6 подотделов и 5 секторов, а штат их в разное время рос от 30 до 50 чел. Соответствующие отделы создавались в партийных комитетах всех уровней, кроме того, при отделах работали разные колиегии и комиссии. С 1922 г. в парткомах появился институт инструкторов. Важную роль играли контрольные комиссии - республиканская, областные и губернские. Они работади с 1921 по 1934 гг., причем республиканская выросла с 5 чел. до 53 в 1925 г. и 75 в начале $1930-х$ гг. ${ }^{8}$

Таб. 1. Перемены численности ответственных работников губрнского масштаба КАССР в 1922-1923 гг.

\begin{tabular}{|c|c|c|c|c|}
\hline Год & Численность (уезд-губерния-край) & Коренизация & \multicolumn{2}{|c|}{ Примечание } \\
\hline 1922 & $662^{*}$ & - & \multicolumn{2}{|c|}{ - } \\
\hline 1923 & $588^{* *}$ & - & \multicolumn{2}{|c|}{-} \\
\hline 1924 & 884 (краевые учреждения) & 33 или $3,6 \%$ & \multicolumn{2}{|c|}{-} \\
\hline 1925 & $\begin{array}{c}1104 \text { (краевые учреждения); } \\
\text { ответработников } 9882\end{array}$ & $\begin{array}{l}92, \text { или } 8,3 \% \\
\text { (всего } 12,5 \%)\end{array}$ & \multicolumn{2}{|c|}{$\begin{array}{l}742 \text { партийных и } \\
\text { советских }\end{array}$} \\
\hline 1926 & 1080 (краевых и губернских) & - & - & - \\
\hline 1927 & 25147 & $2683(23 \%)$ & $\begin{array}{l}\text { европейцев } \\
46\end{array}$ & - \\
\hline 1933 & $\begin{array}{c}130833 \text { (гос. и адм.-хоз.аппарат); } \\
125043 \text { (респ., обл. и рай.аппарат) }\end{array}$ & $\begin{array}{l}39268(30 \%) \\
37263(29,8 \%)\end{array}$ & - & - \\
\hline
\end{tabular}

Истовчник: РГАСПИ, фонд 17, опис 67, дело 83, к. 8-9; опис 68, дело 189; А. Ф. Абоян, Деятельность КРАЙКК-РКИ Казахстана в области партийного строительства и совершенствования государственного аппарата в 1926-1933 г2., Алма-Ата, 1967.

* РГАСПИ, фонд 17, опис 67, дело 83, k. 33-44, 56.

** За исключением Адаевского и Тургайского уездов.

*** О коренизацุии. Сборник руководящзих материалов, Алма-Ата-Москва 1934, s. 40.

В 1924 г. Учраспред ЦК РКП(б) вКлючал в свою номенклатуру 325 ответственных работников губернского масштаба в КАССР. Примерная численность т.н. ответственных работников в 1922-1933 менялась ${ }^{9}$.

${ }^{8}$ Коммунистическая партия Казахстана: организационно-политическое развитие. Справочник, Алма-Ата 1990, 33-36.

${ }^{9}$ РГАСПИ, фонд 17, опис 67, дело 83, k. 8-9; опис 68, дело 189, k. 35-42; Коммунистическая партия Казахстана: организационно-политическое развитие, 33-36; А. Ф. 
Главной отличитедьной особенностью советской номенкдатуры, считает Г.В. Костырченко, „являлось ее самопроизвольное стремительное разрастание ${ }^{\prime 10}$.

Ф. И. Голощекин на VI партконференции назвал состав республиканского корпуса активистов, из которых рекрутировались чиновники: члены аулсоветов, ревкомиссий, профсоюза сельхозрабочих, союза Кошчи, ККОВ, ВЛКСМ, делегаты съездов профсоюзов, потребкооперация, сельхозкооперация, члены горсоветов объединяли 127184 чел. Их он определил как низовой актив. 30341 чел. составил выборный состав массовых организаций. Уездный актив (профсоюзный, укомы, Кошчи, ВЛКСМ, ячейки) - 2916 чел. Губернский актив насчитывал 1725 чел. При этом, указывал он, казахский актив ограничен: „Мы все вертимся вокруг одних и тех же лиц”. Член КрайКК И.Н. Морозов признался, что в государственном аппарате республики „много хиама”, хотя он и был невелик - „всего 47130 единиц”. Сюда входило число работников госаппарата и состоящих на государственном и местном бюджете, хозрасчетных, кредитных учреждений, не считая милиции и некоторых торгующих организаций. При этом учитывался как управленческий, так и т.н. оперативный аппарат - учителя, агрономы, ветврачи и пр. Именно их для Казахстана не хватало. 53\% из этих 47130 чел. составлял административно-управленческий аппарат (25147 чел.). Огромная территория, многонациональность населения, множественность административно-территориадьных частей все это объясняло такой рост численности. При этом аппарат управления „разбухал" в той же пропорции, что и в других республиках СССР, практически копируя их. Наркоматы и другие учреждения не были нагружены работой, занимаясь ее „выдумыванием”, в т.ч. для нижестоящих инстанций ${ }^{11}$.

С 1927 по 1933 гг. численность казахов в государственном и административно-хозяйственном аппарате выросла с 8585 до 39268 чел. $(30 \% \text { всей численности })^{12}$. Т.е., всего чиновников в КАССР было примерно 130833. Число служащих-коммунистов в 1938 г. составило 5726 чел. $(11,8 \%)^{13}$.

Абоян, Деятельность КРАЙКК-РКИ Казахстана в области партийного строительства и совершенствования государственного аппарата в 1926-1933 г2., Алма-Ата, 1967, s. 23-24, maszynopis pracy kandydackiej.

${ }^{10}$ Г. В. Костырченко, Тайная политика Сталина. Власть и антисемитизм, Москва 2003, [Электронный ресурс]. URL: http://krotov.info/libr_min/11_k/os/tyrchenko_6.html (data wejścia: 13 I 2015 r.).

${ }^{11}$ РГАСПИ, фонд 17, опис 25, дело 6, к. 68, 73, 139-145.

${ }^{12}$ А.Ф. Абоян, ор. cit., 23-24.

${ }^{13}$ Ibidem, 94-95, 101. 
Таб. 2. Состав ответработников на конец 1927 г. в КАССР.

\begin{tabular}{|c|c|c|c|c|}
\hline Учреждение & Всего & $\begin{array}{c}\text { В т.ч. } \\
\text { казахов }\end{array}$ & Русских & Прочих \\
\hline Президиум КазЦИК & 21 & 12 & 6 & $\begin{array}{c}\text { каракалпаков - } \\
\text { 1, узбеков - 1, } \\
\text { таранчинцев - } 1\end{array}$ \\
\hline Пленум КЦИК & 131 & 81 & \multicolumn{2}{|r|}{70} \\
\hline $\mathrm{CHK}$ & 17 & 11 & \multicolumn{2}{|r|}{6} \\
\hline Краевые учреждения & 16 & 8 & \multicolumn{2}{|r|}{8} \\
\hline Руководители банков & 8 & 1 & \multicolumn{2}{|r|}{7} \\
\hline $\begin{array}{c}\text { краевые кооперативные } \\
\text { органы } \\
\end{array}$ & 2 & 2 & - & - \\
\hline Председатели губисполкомов & 9 & 8 & \multicolumn{2}{|r|}{1} \\
\hline Заведующие ГЗУ & 9 & 8 & - & 1 каракалпак \\
\hline Заведующие губоно & 9 & 9 & - & - \\
\hline Председатели губсуда & 9 & 8 & - & 1 каракалпак \\
\hline $\begin{array}{c}\text { Заведующие губ. } \\
\text { торготделами }\end{array}$ & 9 & 5 & \multicolumn{2}{|r|}{4} \\
\hline Губ.прокуроры & 9 & 8 & \multicolumn{2}{|r|}{1} \\
\hline $\begin{array}{c}\text { Председатели уездных } \\
\text { исполкомов } \\
\end{array}$ & 32 & 19 & 7 (европейцы) & $\begin{array}{c}6 \text { (восточных } \\
\text { национальностей) }\end{array}$ \\
\hline Народные судьи & 236 & 153 & \multicolumn{2}{|c|}{$\begin{array}{l}\text { узбеков - 3, таранчинцев - 2, } \\
\text { каракалпаков - 6, прочих } 72\end{array}$} \\
\hline Народные следователи & 146 & 92 & \multicolumn{2}{|c|}{$\begin{array}{c}\text { таранчинец - } 1, \text { каракалпаков - } 2 \text {, } \\
\text { прочих - } 51\end{array}$} \\
\hline Итого & 663 & $\begin{array}{c}425 \\
(64,1 \%) \\
\end{array}$ & \multicolumn{2}{|c|}{238} \\
\hline
\end{tabular}

Источник: РГАСПИ, фонд 17, опис 25, дело 7, k. 64.

\section{БОЛЬШЕВИЗАЦИЯ}

Казахская советская этнократия рекрутировалась из представителей разных социальных групп, проявивших официальную солидарность с программными положениями большевистской этнополитики. Несмотря на ее малочисленность и объективно возникавшую отделенность от основной массы общества, решающую роль в интеграции нового руководства в общесоветскую систему управления сыгради разные обстоятельства. Среди них наиболее важными были: заявленная и так или иначе подтвержденная подитическая лояльность, определенный образовательный уровень, некий административный опыт (несмотря на то, что он был связан со службой царскому, Временному правительствам или даже антибольшевистским структурам 
Таб. 3. Соотношение численности населения и управленцев в 1927 г.

\begin{tabular}{|l|c|c|}
\hline \multicolumn{1}{|c|}{ Республика } & $\begin{array}{c}\text { Адм.-упр. Персонала на 10 } \\
\text { тыс. населения (КрайКК на } \\
\text { VI партконф.) }\end{array}$ & $\begin{array}{c}\text { Сотрудников центрального } \\
\text { аппарата на 100 тыс. населения } \\
\text { (по данным НК РКИ РСФСР) }\end{array}$ \\
\hline Казахская АССР & 36 & 12,8 \\
\hline Татарская АССР & 40 & 48,8 \\
\hline Крымская АССР & 96 & 107 \\
\hline Башкирская АССР & 24 & - \\
\hline Дагестанская АССР & 37 & - \\
\hline Марийская АО & 36 & - \\
\hline Вотская АО & 32 & \\
\hline
\end{tabular}

Источник: РГАСПИ, фонд 17, опис 25, дело 6, k. 68, 73, 139-145; А.Ф. Абоян, ор. cit., s. 21.

периода Гражданской войны), убедитедьный авторитет в этносообществе и его регионадыных пластах и не в последнюю очередь - ресурс неформальных дичных связей и контактов с политиками и чиновниками разного уровня и масштаба.

За 1924 г. в результате укрупнения в КАССР вместо 46 уездов осталось 35, вместо 1127 волостей - 552, количество служащих сократилось на $45 \%$. Но обследование Актюбинской губернии показало, к примеру, что „в результате районирования получилось не приближение, а значительное отдаление от населения соваппарата". Повышение квалификации или мобилизация более или менее подготовленных кадров не означали их устойчивое закрепление на местах, причем решающую роль играли плохие материальные и бытовые условия. В Джетысуйской области, как признавало партруководство, „работники бегут из Кошчи”, т.к. по подгода не получают зарплату, а половина коммунистов „выпивали" 14 .

Краевая РКИ по итогам работы с июля 1925 по июль 1926 гг. обнаружила, что т.н. болезненным явлениям больше всего оказались подвержены именно служащие, причем чаще всего это были пьянство (36\% служащих) и уголовные преступления (4,3\%). Один из руководителей республики признавал, что из 16 низовых работников 14 - взяточники. Среди партийцев КАССР т.н. болезненными явлениями было охвачено 8,2\%, тогда как по всему СССР - 7,6\%. Самые распространенные - пьянство, растраты, взятки, превышение власти - по этим вопросам в краевой контродьной комиссии рассматривалось

${ }^{14}$ РГАСПИ, фонд 17, опис 68, дело 184, k. 30, 46, 52; V Всеказахский (Всекиргизский) съезд Советов, „Виасть Советов” 1925, nr 23-24, 25-26. 
в 1926 г. 208 дел коммунистов, причем ответственные работники чаще всего попадали туда за пьянство. Как заметид в связи с этим докладчик от краевой контродьной комиссии на VI партконференции И.Н. Морозов, „ответственные работники в КССР нуждаются в серьезном партвоспитании". К тому же, число жалоб по поводу бюрократизма за время от V до VI партконференции выросло на 296\% ${ }^{15}$.

“Партийно ассимилировать в партии казакскую массу, казакскую руководящую часть - это большой и трудный процесс" - говорил на VI краевой партконференции Голощекин (ноябрь 1927 г.). В связи с районированием он предложид основную работу по выдвижению возложить на губкомы. При этом хорошим работникам он обещал: после наблюдения „возьмем себе, а плохое пошлем вам перерабатывать (смех)”. Он выдвинул дозунг: „Новые кадры к руководству - дальше большевизировать нашу партию!". При этом мотивом к отказу от т.н. процентной коренизации было следующее: „[...] обнаружили, что на основе политики прошлого периода мы выбрали в партийный, советский, профессионадьный и хозяйственный аппараты все грамотное и полуграмотное, что было и есть среди казаков (киргиз)"16. Именно неразвитость системы образования и объективная невозможность в кратчайшие сроки получить образованных управленцев была главной причиной проблем с коренизацией. Однако партбюрократия сосредоточилась на функциональном составе национальных кадров.

Контроль за дояльностью чиновничества осуществляли партийные органы. Система чисток, проверок, обмена партбилетов как формы „очищения” от некомпетентных или не проявивших должной ответственности и другие формы возникди и апробировадись в довоенный период, а затем стали важной частью институциональной и кадровой практики.

В частности, уже в 1919 г. прошла перерегистрация коммунистов, в 1920 г. в связи с введением единого образца партбилета она была проведена вновь. С августа 1921 г. по февраль 1922 г. шла чистка рядов партии в республике, когда целью стали не только кулацкие элементы, но и бывшие члены других партий. Всего было исключено, выбыло или переведено в кандидаты 19,5\% состава парторганизации республики. Весной началась Всероссийская партийная перепись с обменом документов, в 1922-1924 гг. контродьные комиссии парткомов КАССР вынесли решения об очищении от 1512 чел., „не оправ-

${ }^{15}$ Государственный Архив Жамбылкской Области (ГАЖО), фонд 10, опис 1 , дело 345, k. 26-27; РГАСПИ, фонд 17, опис 25, дело 6, k. 62v, 73, 139-145.

${ }^{16}$ РГАСПИ, фонд 17, опис 25, дело 6, k. 49, 71v, 73v. 
давших доверия". В 1925 г. состоялась проверка непроизводственных партячеек, в 1925-1926 гг. - выборочная проверка аульно-сельских, в 1927 г. - Всесоюзная партперепись с обменом документов, причем число коммунистов и кандидатов в республике снизилось почти на 2 тыс. чел. Оказалось, что служащие в составе республиканской парторганизации составили 21,2\%, высшее образование имели лишь 55 чел. из общего числа партийцев (33163 чел.), среднее - 964. Казахи составиди $35,3 \%$ коммунистов ${ }^{17}$ республики - именно они являлись главной силой управленческих структур и всяческих руководящих инстанций в условиях проходившей коренизации.

Петом 1929 г. по решению ноябрьского 1928 г. пленума ЦК и XVI конференции ВКП(б) началась новая генеральная чистка. Именно в 1929 г. она была распространена и на беспартийных служащих советских учреждений, и под чистку рисковади попасть чиновники по самым незатейливым поводам, поскольку критерии были неточными. Она проходила до мая 1930 г. и охватила буквально все слои управленцев: от аппаратов Казкрайкома партии и СНК КАССР, других краевых учреждений и ведомств до нижестоящих в округах, районах и на местах. 5800 чел. или 15,2\% коммунистов были исключены из партии, „механически” выбыли 750 чел., в т.ч. из учреждений исключено 839, выбыло добровольно - 5, механически - 38, выговор был объявлен 876-ти. За бюрократизм (можно предположить, что это были чиновники) было искдючено $3 \%$ от общего числа исключенных, по мотивам, которые могли касаться чиновников, - должностные и уголовные преступления $-22 \%$, группировки $-2 \%{ }^{18}$. Но качество управления и кадровый потенциал эти меры не улучшили, поскольку репрессивная практика не только не прекратилась, но и продолжала расширяться.

Все эти акции провоцировали конфликтные отношения, стремление использовать спущенные сверху механизмы в борьбе амбиций и для удовлетворения карьерных интересов путем устранения соперников. Достаточно активно практиковались с этой целью частые ротации работников из одних регионов в другие под всевозможными благовидными предлогами (а не менее частые административно-территориальные преобразования давади еще один повод для этого), что позволяло отстранить от ключевых постов неугодных и выдвинуть сторонников. Определенную родь игради также родственные

${ }_{17}$ Коммунистическая партия Казахстана: организационно-политическое развитие, 37-38, 67; Движение Алаш: сб. документов и материалов, t. 1, ks. 1, Алматы 2007, s. 115.

${ }_{18}$ Коммунистическая партия Казахстана: организационно-политическое развитие, $67-68,90$. 
и клановые связи, хотя придавать им решающее значение во всех случаях вряд ли правомерно.

В результате политизации этничности, реструктуризации социального ландшафта, масштабных образовательных программ, модернизации социально-экономической сферы резко выросло число образованных людей - представителей титу дыных этносов, в т.ч. казахов, во всех областях общественной жизни. В то же время качественно новая политическая система требовала не просто образованных чиновников. Была выстроена и реализовалась практика идейно-политической подготовки и карьерного роста управденца, когда на каждом отдельном этапе и в каждом отдельном звене при их неразрывной взаимной увязке он систематически проходил серьезную проверку на идеологическую „чистоту”, ответственность, умение подчинять дичные цели интересам (делам) партии, организаторские навыки и т.д. Общекультурная подготовка новой бюрократии была гораздо слабее уже в силу ее экстремальной краткосрочности. Взамен выросших в начале 1920-х гг. проявлений мздоимства, „комчванства”, гонки за престижным потреблением власть организовала продуманную иерархическую систему мер материальной и социальной поддержки чиновников, которая служила важным стимулом к строгому соблюдению корпоративной дисциплины, безусловному исполнению служебных обязанностей, преданности официальной идеологии.

\section{ЭТНИЗАЦИЯ}

Глава КирВРК С.С. Пестковский, 1919 г.: „Когда у нас будет некоторое число киргизских работников коммунистов, тогда наступит время для решительных действий. [...]. Необходимо взяться за создание советского аппарата на местах с помощью местных сил. Необходимо в Киргизии создать честную советскую бюрократию». К 1924 г. казахи составляли 38\% работников уездных парторганов ${ }^{19}$.

Краевые органы были коренизированы к 1925 г. на 8,3\%. На 1 октября 1925 г. казахов во всех аппаратах республики было 272, на 1 июля - 485, в т.ч. руководителей и их заместителей - 50 и 43, заведующих отделами и их заместителей - 31 и 36, зав. подотделами и их заместителей - 19 и 20. Удельный вес казахов достиг 14,4\%, в аппаратах их стало 12,5\%. Уровень укомплектованности национальными кад-

19 РГАСПИ, фонд 17, опис 86, дело 129, к. 88; опис 68, дело 53, k. 150; дело 58, k. 19, 26, 38; А. И. Мирзоян, О проекте Конституц̧ии Казахской ССР. суt. za: Антология социиально-политической мысли Казахстана с древнейших времен до наших дней (в двух томах), Алматы 2002, 450. 
рами чиновников тех иди иных управленческих структур был обусиовлен их ролью в непосредственной работе с населением, а также в немалой степени наличием квалифицированных кадров в конкретных отраслях хозяйствования. В начале 1926 г. удельный вес казахских служащих в органах исполнительной власти и управления оставался неоднородным: Наркомпрос - 50\%; Казотделение Верховного суда и Казторг - 48\%; Наркомюст - 39\%; Наркомсобес - 36,5\%; Упсырзаг $36 \%$; Наркомвнудел - 34\%; Казкрайсоюз - 29\%; Казсельхозбанк - 28\%; Казхлебторг и Казмясопродукт - 27\%; Наркомтруд - 21\%; Крайсоцстрахкасса - 20\%; Наркомзем - 16,9\%; КЦИК, СНК, Госплан - 15\%; Текстсиндикат и Кожсиндикат - 13\%; Наркомвнуторг - 9,5\%; Казгосторг - 8\%; Хлебопродукт - 7\%; Казомес - 4\%; Управление округа связи $3,3 \%$; Наркомвнешторг $-0 \%{ }^{20}$.

Выступая на 2-й Сыр-Дарьинской губпартконференции в декабре 1926 г., 2-й секретарь Казкрайкома ВКП(б) У.Д. Исаев так объяснял задачи коренизации: „[...] это есть приближение аппарата к массам, а не казакизация, как это многие понимают. Посредством коренизации полагаем сделать понятным, доступным и близким аппарат к основной массе Казакстана. ...это является главной предпосылкой к советизации аула. [...]. Первыми шагами был поставлен вопрос казакизации аппарата, т.е. \% соотношение национальностей в работе соваппарата. Но это безусловно неправильно. Я укажу на пример: коренизуется Губфо, там нужно провести коренизацию налогового п[од]/отдела, как близко соприкасающегося с массами, а другие п[од]/отделы, как, например, контрольно-бухгалтерский, можно оставить вне коренизации, пусть там сидят европейцы. Крайком отверг метод казакизации и ввел функциональную коренизацию» ${ }^{21}$.

Д. Садвокасов отметил на VI партконференции (ноябрь 1927 г.): „Никому не секрет, что в Казакстане на руководящих постах сейчас, в основном, сидят коммунисты националы-казаки". Однако признал он, теперь, в отличие от 1920 г., „нужно самих себя перевоспитать в интернациональном духе". Голощекин подчеркивал в 1929 г. на V пленуме Крайкома партии: „Мы не можем коренизировать потому, что у нас недостает кадров”. При этом подчеркивалось: „[...] особо остро должен быть поставлен вопрос о классовом подборе и идеологии" 22 . Массовый призыв во власть т.н. выдвиженцев из представителей социальных низов, наряду с кампанией по оживлению

${ }^{20}$ РГАСПИ, фонд 17, опис 69, дело 61, к. 95; Вехи консолидациии, 82-95, 164-166.

${ }^{21}$ ГАЖО, фонд 10, опис 1, дело 345, k. 12.

${ }_{22}^{2}$ РГАСПИ, фонд 17, опис 25, дело 6, k. 88; дело 7, k. 63; Ф. И. Голощекин, Казакстан на путях социалистического переустройств, Москва-Алма-Ата 1931, 231. 
советов, должен был укрепить социальную базу советской системы. Однако реальная слабость низового актива, наряду с бюрократическими методами самих мероприятий, не давали быстрого результата. Спешная казахизация не могла улучшить качество управленческого персонала.

В апреле 1928 г. по аналогии с общесоюзными изменениями объединенный пленум Казкрайкома и КрайКК ВКП(б) принял решение „О районировании Казахстана”: вместо 6 губерний и 42 уездов республика делилась на 12 округов и 189 районов. Предполагалось, что выделение этнически однородных районов ускорит выдвижение в аппараты управления представителей титульного этноса и развитие двуязычия среди управленцев. Районирование считалось также способом преодолеть родоплеменные скрепы между территориями, поскольку новые административные единицы должны были создаваться на основе экономической и географической целесообразности. Однако уже в августе 1928 г. округа были упразднены, вместо 189 районов образованы 123. Управляемость вследствие этих перетрясок не улучшилась. Для чиновников они означали дополнительные реорганизации, зачастую малооправданные интересами дела перестановки по службе. „По существу Казкрайком партии утерял живую организационную связь с рядом райкомов"23, - за этой констатацией партийного издания 1990 г. стоит признание фактической деградации и хаотизации системы управления и ее кадрового состава.

По мнению И. Огайон, административно-территориальные изменения 1920-х гг. служили элиминации родовых отношений, поскольку клановая идентичность и межродовое соперничество в условиях новой системы управления должны были сокращаться или вообще становились невозможными., а проведенное в 1928 г. районирование способствовало разобщению казахов при их внешнем территориальном единстве. „,...] новое административное деление позволяло осуществлять глобальный контроль всей территории, облегчало слежение за регионами, заселенными казахами и их образом жизни и, как следствие, эффективно осуществлять репрессивные меры: конфискацию, а позже колиективизацию и седентаризацию" 24.

Уже в начале февраля 1931 г. на объединенном пленуме Казкрайкома и Краевой КК Голощекин заявил, что „ликвидация округов, несомненно, дала огромные плюсы", но приведенные им тут же фак-

${ }^{23}$ Коммунистическая партия Казахстана: организацчионно-политическое развитие, 63.

${ }^{24}$ И. Огайон, Седентаризацุия казахов в СССР при Сталине. Коллективизацุия и соцุиальные изменения (1928-1945 г2.), Алматы 2009, 46. 
ты свидетельствовали об обратном. После публикации решения ЦК о ликвидации округов, говория он, „началась дезорганизация: окружные учреждения перестали работать". В таких условиях осуществлять „глобальный контродь всей территории, слежение за регионами”, как считает И. Огайон, руководству республики и уж тем более Москвы на деле вряд ли удавалось. Огромные расстояния в Казахстане при отсутствии телеграфной и телефонной связи, сосредоточенности бюджетных средств в городах делали планы центра заведомо лишенными практической пользы и невыполнимыми ${ }^{25}$.

Однако, как и прежде, борьба за доступ к административному ресурсу была важнейшей частью комплекса мер по отстаиванию реальных и символических атрибутов верховенства родов. Бюрократия, где „бастык” априори выступал в качестве особо уважаемого человека и носителя высшей мудрости, быстро превращалась из инструмента власти в само ее воплощение. Официальная коммунистическая идеология воспринималась на поверхностном уровне и нередко носила маскировочный характер, хотя были и национальные кадры - убежденные коммунисты. По существу, тотальную селекцию кадров власть произвести не могла, поскольку архетипы социальной иерархии и традиционные способы коммуникаций между разными социальными группами встраивались в советскую схему. В итоге произошла как бы реинкарнация байства, когда начальник рассматривался и утверждался в роли „патриарха”, уважаемого главы учреждениясемьи. Номенклатура партийно-советских органов дублировалась, а нередко и подменялась номенкдатурой родоплеменной ${ }^{26}$.

По формальным показателям социально-политическая активность казахов при этом повышалась из года в год. Сконструированная в советское время этнополитическая элита и интеллигенция, предпочитая ценности стабильности и компромисс с властью, при сохранении формального верховенства союзного центра и бюджетных ассигнований в пользу республик успешно овладевала господствующими позициями на региональном уровне. Этнобюрократия активно использовала дисциплину обычного права (делегирование полномочий по представительству и защите интересов по традиционной социальной иерархии), партийную борьбу против оппозиций

${ }^{25}$ РГАСПИ, фонд 17, опис 25, дело 22, k. 189; дело 58, k. 11-47; ЦК РКП(б)-ВКП(б) и национальный вопрос, ks. 1, Москва 2005, 644-647.

${ }^{26}$ И.В. Стадин неоднократно говорил о низком культурном уровне „целого ряда наших организаций, наших ячеек, особенно на окраинах [...]", на XIII съезде РКП(б) приводил данные о том, что удельный вес политически неграмотных членов партии достигает 60\%. Zob. И. В. Сталин, Сочинения, t. 6, 11. 
во внутриэтническом соперничестве, обеспечивала этносоциальную перекодировку символов и атрибутов власти, форм и инструментов управления. Вместо прежних „жаксылар" (главы родов, бии, батыры) правили новые - советские чиновники. Социальные дистанции приобретали новое качество. Дополнительную остроту борьбе националов придало размежевание, усидив их стремление к перегруппировке регионов и персон влияния на фоне конструирования этнической консолидации сверху.

Курс на коренизацию аппарата, взятый большевиками, стремящимися втянуть степняков в доно мировой пролетарской революции, принес закономерные, но своеобразные плоды. Советская элита Казахстана оказалась тоже мозаичной по составу, выросшей совсем не только из самых социальных низов. Особую роль играла солидарность на уровне базовых общностей, наличие особых социальных практик функционирования субэтничностей.

\section{BIBLIOGRAFIA:}

Абоян А. Ф., Деятельность КРАЙКК-РКИ Казахстана в области партийного строительства и совершенствования государственного аппарата в 1926-1933 г2., Алма-Ата, 1967.

Аманжолова Д. А., Казахское общество в 1-й четверти ХХ века: проблемы этноидентификации, [w:] Россия и Казахстан: проблемь истории (XX - начало ХХІ вв.), Москва 2006.

Вопросы истории Компартии Казахстана, выпуск 6, Алма-Ата 1969.

Костырченко Г. В., Тайная политика Сталина. Власть и антисемитизм, Москва 2003, [Электронный ресурс]. URL: http://krotov.info/libr_min/11_k/os/tyrchenko_6.html.

Огайон И., Седентаризация казахов в СССР при Сталине. Колхективизациия и социальные изменения (1928-1945 г2.), Алматы 2009Яковенко О. А., История административно-территориального деления Центрального Казахстана в ХХ веке, „Вестник КарГУ” 2005, nr 2(38).

FORMATION OF THE KAZAKH SOVIET BUREAUCRACY IN 1920s: BOLSHEVIZATION OR ETHNICIZATION?

\section{ABSTRACT:}

The formation of the Soviet state, its transformation and stabilization in the 1920s and 1930s on the example of how the political elite of Kazakh Soviet Socialist Republic was formed and restructured portrays the dynamic nature of political culture and ambivalent character of Soviet ethnopolitics. Personalization of the relationships of management and subordination, dynamic development of bureaucratic structure and its culture indicate the multi-threaded character of mutual relations between the traditional society and the emerging modernising factors. An important issue are also ways of strengthening the political 
culture of federative statehood through consolidation of the ruling elite and consolidating the mutual relations between the central authorities of the Soviet Union and authorities of the republics which the Union comprised. The author analyses processes occurring during the formation of Soviet bureaucracy in Kazakhstan. She portrays the degree and areas of its unification or modification under the influence of ethnic and social factors as well as peculiarities and modernising processes taking place within the bureaucratic system.

Key words: Kazakhstan, Soviet Union, bolshevization, bureaucracy, politics

NOTA O AUTORZE:

Dina A. Amanzholova (Дина Ахметжановна Аманжолова), dr hab., profesor i pracownik naukowy Instytutu Rosyjskiej Historii Rosyjskiej Akademii Nauk, autorka kilkuset publikacji na temat kwestii narodowych i etnicznych w Imperium Rosyjskim i Związku Sowieckim, e-mail: amanzholova19@mail.ru 